
a contingent apparition of real readers. Slavia Meridionalis, 17. https://doi.org/10.11649/sm.1232

\title{
Vedad Spahić
}

Faculty of Humanities and Social Sciences

University of Tuzla

\section{How to Read Hasan or the Resurrection of a Contingent Apparition of Real Readers}

An aggressive tendency exists with us, to keep the perception of certain Bosnian writers within the hedges of formalism/intricism, stemming from (for some) the pleasant 1970s, when the shift of critical-theoretical foreshortening towards the (re)contextualization of reading of the literary text, with the exception of the triaged biographism and Marxist class-historical reductionism, came to be understood as a potential threat to one's status of dedication, and, what's more, an enormous personal, existential risk. Such attempts were scarce at the time, although poststructuralism had already been encompassing critical and academic space. That was the time when Professor Foht lamented in an Adorno-like manner over the rez-de-chaussee of banalism through which a mass of perennially incompetent readers hopelessly rummaged, ontologically separated and are never within reach of the spiritualized heights of the fine art and literature. His poignant laments still dimly resonate:

The work has been prepared at author's own expense.

Competing interests: no competing interests have been declared.

Publisher: Institute of Slavic Studies, Polish Academy of Sciences.

This is an Open Access article distributed under the terms of the Creative Commons Attribution 3.0 PL License (creativecommons.org/licenses/by/3.0/pl/), which permits redistribution, commercial and non-commercial, provided that the article is properly cited. (c) The Author(s) 2017. 
The receiver will in the vast majority of cases experience a work of art only when confronted with the known reality or, what's worse, will approach the work of art only if able to 'find' something that is in accordance with his personal experience from everyday life; he will observe the novel's protagonists as his neighbours, or as a negation of his neighbours. If the receiver does not observe the work through his world view, then one other case of inadequate relationship towards the aesthetic object occurs: he does not surrender, he does not give in, he does not dwell on it and its specifically aesthetic content, rather, his gaze reflects against the surface and outer features of the object, constantly, persistently and consciously or subconsciously running into - associations, into the content that has nothing to do with the work itself (Foht, 1980, p. 46).

In the meantime, a complete turnabout occurred - literary theory and criticism, interwoven with psychoanalysis, cultural, gender, and postcolonial studies, completely opened new ways of perception and started putting different questions before the literary text, related to issues from a gender perspective, social context, identity and, of significance to us, also the question of the implicit and explicit reader; the former as "an active character of reading outlined in the text" and the latter who is biographically, socially, and historically determined (Iser, 1986, p. 280). Approaching the issue in a wittier and more imaginative manner, Umberto Eco compares the reader to a man walking through a forest and who can display different kinds of behavior. He can go through the forest running from one end to the other, without observing trees, flowers, smells, birds and he can walk differently, strolling, carefully observing everything around, questioning the hidden corners (Eko, 2003, p. 76). It seems that the most numerous is the category of people who do not loiter much yet only stop at precisely determined areas where they are able to please their thirst for cognition, but through a narcissistic pseudo-cognitive confirmation of their own pre-convictions. The vast majority of readers of Selimovićs novel Death and the Dervish (1966) belong to this category; the ones looking for and "finding" almost exclusively political and autobiographical content, connected to the events in the writer's life on a very superficial and allegorical level. Still, judging by some recent generalizations on this topic, that the multitude of readers are unable to avoid the role of reading oneself in the voice that de profudis unmistakeably testifies to the truth for themselves alone:

For Bosnian Muslims, this book has borne testimony on their identity through fiction, like no other... Meša Selimović has approached Bosnian Muslims so close to have become their literary voice and messenger. Such a writer had not only never existed, but there also had not been even a slightest intimation of such a possibility (Jergović, 2015). 
Rhetorical monumentalism is characteristic of today's opinion journalism, which, in reality, does not even appeal to the fast, interest-driven passersby through the "narrative forests", while the professional "forestarium", that is, the established critical praxis in the majority of cases still nurtures some form of reductionist reading. Observed diachronically, two types have been predominant. In the first type of the narrowed reception, the author and a multitude of ephemeral facts regarding his life came to be more important than the work itself (Popović, 1988; Lagumdžija, 1991), analogous to the situation amusingly described by Roman Jakobson when he compared such dealing with "literature" to a police officer who "while arresting a certain individual also arrests all other people present at that moment in the flat, including some accidental passers-by." (Jakobson, 1970, p. 102). The other type of reduction of Selimovićs works to inappropriate levels is related to the pseudo-cognitive approaches that comprehend a literary work as a means to reach some essence that exists outside it. In that sense, the text does not produce a meaning; it merely points to an existing sense, completely unrelated to the text. A fragment from the novel Death and the Dervish, the popular Hasan's monologue on the Bosniak identity to which this essay is dedicated, is exceptionally appropriate for interpretative manipulation through the text as an ostensible verification of something that exists even without the literary work, and that, as a rule is, as noted by Gajo Peleš "a totality, a closed representation of the world which, for the very reason that it is closed towards the different, does not even count on the text as an insight into the unknown, but as a confirmation for what it is by itself" (Peleš, 1984, p. 175).

Under the cover of the cognitive, the understanding of literature on such a plane fails entirely for not only does it suspend the very possibility of literary cognition as an autonomous insight into reality, but it also sees it as a repetition of other proposed determinations.

Thus we are sketching the contours of a platform from which we will closely observe ${ }^{1}$ the significant monologue of Meša's novel, fully aware of

1 "Close observation" is here to be understood as an (unwilling!) respect towards the discursive and theoretical consequences of the artistic mainstream practice of the past century. One of the writers who least favored them, when observed through trends, was Milan Kundera, who essentially denied that the divergence of aesthetic and life trends, so characteristic of modernism: "Aesthetic concepts only began to interest me when I first perceived their existential roots, when I came to understand them as existential concepts: people simple or refined, intelligent or stupid, are regularly faced in life with the beautiful, the ugly, the sub- 
the suspiciousness of the interpretation where, within the holistic hermeneutical tradition, the whole comes second and where a fragment is in focus. Hence, our first reading is an attempt to cast light upon the aesthetic efficiency of Hasan's soliloquy in the context of the structure/the whole of the novel. The other view reads the monologue as an auto-imagological, politically instrumental discourse in which Hasan presents his view of the historical-national (identitary!) fate of the Bosniak ethnos ${ }^{2}$. In spite of the global post-structural acquisitions stemming mainly from left-oriented academic circles, in a recent domestic milieu (our!) second approach still bears an apocryphal sign. Here, the discussion that ended in Europe and America in the first half of the 1980s is just beginning. Terry Eagleton and Vladimir Biti are amongst those who sublimate it and show the hypocrisy and cunningness of formalist criticism:

Few teachers or reviewers are likely to penalize an account of Holderlin or Beckett because it differs from their own. Rather more of them, however, might penalize such an account because it seemed to them ,non-literary' - because it transgressed the accepted boundaries and procedures of ,literary criticism'. Literary criticism does not usually dictate any particular reading as long as it is ,literary critical'; and what counts as literary criticism is determined by the literary institution. It is thus that the liberalism of the literary institution is in general blind to its own constitutive limits (Eagleton, 1987, p. 103).

The only complete reader, according to them [formalists and structuralists - V. S.] would be a theoretician or a poetician, for he possesses the necessary knowledge to make certain contextual distinctions within the perspective of which the text is recognized as literary. Other readers would, through their valorizations, introduce an inappropriate dimension of ideology, psychology, sociology and the like into the literary system and would thus exit the area of literary science. Still, with all the authority literary scientists possess (mainly in their own minds), it is difficult to comprehend the notion of literature through their taste alone. Don't authors, publishers, educators, amateur readers, critics, aestheticians, even politicians form literature just as much? On the other hand, aren't poets themselves always marked in advance by never completely awoken preferences of the artistic taste of their

lime, the comical, the tragic, the lyrical, the dramatic, with action, peripeteia, catharsis, or, to speak of less philosophical concepts, with agelasty or kitsch or vulgarity; all these concepts are tracks leading to various aspects of existence that are inaccessible by any other means". (Kundera, 2015, section 4).

2 There have been literary critics who interpreted the same text in accordance with the patterns of different, even completely opposite interpretative models. Books by Frederick Crews, The Pooh Perpleh (1963) and Postmodern Pooh (2001), are probably the most famous examples where Winnie the Pooh is observed through different perspectives. 
gender, generation, class, civilizational and cultural milieu? What grants them the liberty of eliminating different tastes from such a point of view?... In spite of all the attempts of theorists to eliminate it in favour of textually supervised instances, the contingent weakness of the real reader is constantly returning to the problem (Biti, 2000, pp. 56, 251).

What falls well within the class of the previous statements is a conviction that the interpretation tending to be self-conscious and non-hypocritical is allowed to compare the hero's itinerary of the embedded fabula as well as some of his personality traits with the author's biography, but we reject the

completely unprincipled approach, which is based on fusing the author-creator (a constituent in a work) with the author-person (a constituent in the ethical event of life), on failing to understand the creative principle in the author's relationship to a hero. The result is a miscomprehension and distortion of the author's ethical, biographical personality, coupled with the failure to understand the whole of the work (Bahtin, 1991, p. 11).

The implication of this approach is an absolute irrelevance of the writer's self-reference on the work, topic, or issue the interpretation deals with, even in instances when, as is our case, Selimović directly confirmed the private identification with the attitudes of the literary hero, which can be found in an interview he gave upon receiving the NIN award for the novel Death and the Dervish; he presented ethnic self-definitions from Hasan's monologue as his own (Selimović, 1975b, p. 323).

It is thus our aim to seek answers to the following questions: 1) to what extent is the literary potential of an excerpt, as a constituent of the novel, resilient to non-literary usage; 2 ) to what extent are the literary values beyond the reach of the mass of average readers who read Hasan's monologue and other works by Selimović as historical-political testament for the present and future generations, condemned to forever interpret the dark places, burdens, and erosions of presentations on their own selves. While Hasan/Meša tells us:

We are no one's, always at a boundary, always someone's dowry. Is it a wonder then that we are poor? For centuries now we have been seeking our true selves, yet soon we will not know who we are, we will forget that we ever wanted anything; others do us the honor of calling us under their banner for we have none, they lure us when we are needed and discard us when we have outserved the purpose they gave us. We remain the saddest little district of the world, the most miserable people of the world, losing our own persona and nor being able to take on anyone else's, torn away and not accepted, alien to all and everyone, including those with whom we are most closely related, but who will not recognize us as their kin. We live on a divide 
between worlds, at the border between nations, always at a fault to someone and first to be struck. Waves of history strike us as a sea cliff. Crude force has worn us out and we made a virtue out of a necessity: we grew smart out of spite...

Jamail is our image... Strength on mutilated legs. His own executioner. Abundance with no direction or meaning. The most complicated people on the face of the earth. Not on anyone else has history placed the kind of joke it's played on us. Until yesterday we were what we want to forget today. But we haven't become anything else. We've stopped halfway on the path, dumbfounded. We have nowhere to go anymore. We've been torn away from our roots, but haven't become part of anything else. Like a tributary whose course has been diverted from its river by a flood, and no longer has a mouth or a current; it's too small to be a lake, too large to be absorbed by the earth. With a vague sense of shame because of our origins, and guilt because of our apostasy, we don't want to look back, and have nowhere to look ahead of us. Therefore we try to hold back time, afraid of any outcome at all. We are despised both by our kinsmen and by newcomers, and we defend ourselves with pride and hatred. We wanted to save ourselves, but we're so completely lost we don't even know who we are anymore. And the tragedy is that we've come to love our stagnant tributary, and don't want to leave it. But everything has a price, even this love of ours. Is it a coincidence that we're so overly soft-hearted and overly cruel, so sentimental and hard-hearted, joyful and melancholy, always ready to surprise others and even ourselves? (Selimović, 1975a, pp. 418-419).

Literature, by nature, cannot serve reality. It is within the realm of possibility. Without the premise of modality, it is impossible to understand literature. To paraphrase a well-known critic, writers have blown large, encompassing bubbles that shine a full spectrum, and in that world only do the humans described live their truth - although, of course, they bear recognizable similarities with real people. A character in a novel is not an image or a reflection of some real person, rather a hub of the writer's visions and ideas, hence, inevitably, it is a function within the defined structure of relationships in the fictional world of a literary work. Theoretical schools of an inner approach placed this issue at the very center of the research attention and have attempted to mark even more clearly the autonomy of the fictional sphere tying it to the essence of the aesthetical function, which makes the literary usage of language serve its own purpose. In a word, a language expression is not directly related to the reality outside the language and the referential character of the sign weak- 
ens because it becomes a part of the textual context. The meaning of Hasan's monologue is determined primarily by the principle of the hermeneutical circle, that is, by the function it has within a whole through the relationship with other components. As a personal narrative, from the point of view of characterization, words that Hasan utters are appropriate to him. In the multitude of relationships between characters in the novel, Hasan is the embodiment of the freedom of life's choice and a renaissance of spontaneity of spirit feeding on curiosity and doubt, keeping away from all forms of dogmatism. As such, he stands as a dialectical counterpart to Ahmed Nurudin who is well convinced in the harmony of the Divine order on heaven and earth in the first part of the novel, into the "sense of the world of the Islamic tradition whose opinions and living meant peace and clarity, harmony and oneness of the world and life" (Ustamujić, 1990, p. 57) . As protagonists in the novel structure, Hasan and Ahmed Nurudin make up a pair in the binary opposition of Greimas-Hjelmslev square that can be schematized:

$$
\begin{gathered}
\mathrm{A} \text { - opposite } \mathrm{B} \\
\text { just as is } \\
-\mathrm{A}-\text { opposite }-\mathrm{B}
\end{gathered}
$$

A certain young landowner (A) from the edge of town symbolizes at the beginning of the novel a revolt against the authority = convention (B). Another binary opposition Hasan $(-\mathrm{A})=$ the lack of convention opposite Nurudin $(-B)=$ passivity, ostensible lack of convention, but in fact it is an implied convention. In the moment when Nurudin becomes explicit convention (B), that is, a khadi, Hasan, to whom nothing changes in life, loses the minus and becomes (formally as well, although in essence he has always been) a danger to the convention because he cannot remain close friends within the system of power where Nurudin is immediately involved. In fact, Nurudin himself signs an execution order for Hasan and it is a confirmation of the rule by which a government functions: an individual, whom he is vengefully looking for, is not behind the execution of Nurudin's brother; rather, it is an entire system in which repression is modus vivendi. If one is to read Hasan's monologue through the prism of the entirely relativizing renaissance worldview as a feature of the octant function $-\mathrm{A}$, his ethnogenetic identitary considerations will appear as another efficient gesture of constituting this complex but by no means contradictory character. The principle of internal necessity functions 
both in the dynamics of Hasan's thoughts and actions, as well as in the compossible positioning towards other characters. Hence, the monologue seems more convincing both as an auto-imagological discourse within the entirety of the novel, and separated from the whole for certain purposes. Politics and art differ in the way they approach even the same entities and topics - politics treats an entity as an object, while art approaches it from within; it identifies with it and brings it into connection with a concrete human character which, if portrayed in a trustworthy manner, will gain the trust of the reader.

The fact that one such highly stylized text can function both as a literary work and as a political text can be explained by an everlasting metaphoric quality of language. "It is wrong to believe that language is literally literal. Philosophy, law and politics function through metaphors, just as poetry, so they are equally fictional." (Eagleton, 1987, p. 142) This claim made by Eagleton does not sound as menacing as it did in the 1980s, when it was launched; in the meantime, functional styles were restratified. A highly artificial text can to a significant extent be domesticated in different communicational contexts. Aiming at the recipient ready to examine the aspects of personal and collective identity, the one who sees literature as an opportunity to "formulate himself through the formulation of the unformulated" (Beker, 1986, p. 81), Selimović plays at the cognitive verges, close to acknowledgement: "For it to become what I feel, what I cannot reach through my mind when I think about myself and the people I belong to". Stylistic accomplishment as catalysis, as a helping hand to bridge the gaps of meaning, should at no point be underestimated. The key is in both the multitude and variational diversity of symptoms constituting an utterance as a stylistic complex. The accumulation of figures does not compromise the continuity and unity of a monologue. The expression is unobtrusive. Although antithetically juxtaposed, meanings within the same thought, within the same sentence, merge into a unique impression through subsequent shifting and close association. There are no sudden shifts, hiatuses and collisions - the plays run smoothly, continually and affect one another; they intertwine, support and merge. Links in the semantic chain are variational and gradational, and through a precise usage of one procedure or the other (variation or gradation) the shift from the literal to the metaphorical sense and vice versa is balanced and subtle.

The intristic interpretative approach to which we wish to remain loyal in this part of the interpretation, rejects the opinion that Hasan's virtuous anaphoric succession of thoughts and a lucid method of deriving conclusions is 
unquestionable in terms of style, but messages from the monologue should be deemed unacceptable. Such an opinion amounts to an anachronous dichotomy of "form" and "meaning". Hasan's worldview emerges from the novel as a structural fact, not as a pamphlet in which the writer presents autodefinitions filled with some non-literary goals aimed at presenting his attitudes about the Bosniak ethnogenesis, or to supposedly "trustworthily" present the situation in the real world. Even when the author himself explicitly identifies with the hero's attitudes, when he believes that the hero's utterances match the reality, such testimonies do not possess absolute value in aesthetic communication, postulated on the basis of Leibniz's theory of possible worlds (Leibniz, 1980). Aesthetic decoding of the text gives primacy to the internal relationship over the real author, just as it superordinates the category of the possible over the category of the real, looking for an answer to the question is the world of a literary work possible, that is, is it internally coherent. The measure of its truthfulness lies in the compossibility of the elements comprising it and as a possible world it never repeats something that already is or has been achieved in that way anywhere else. The reader reconstructs that world, not other worlds, hence, seen from such an angle, Hasan's monologue can be identified with the historical fate of the Bosniak people to the extent that the world of Dickens can be identified with London, Joyce's with Dublin, Kafka's with the old Prague. All those worlds are projected in writing and then through the free and non-binding associations of readers; they are recognized in the empiric world as Dickens' characters, Joyce's itinerary, Kafka's situations, so that such identifications, as emphasized by Wellek and Warren, "seem completely meaningless" (Velek \& Voren, 1974, p. 211). The intrinsic approach in literature separates the ontologically artistic from the propositional truth - here, untruth is "a complex failure, not a function of negation" (Langer, 1967, p. 349). Reception that surpasses an elaborated conception falls into an eerie category of hypothesizing. And to that we let go, fully aware and on purpose.

\section{II}

High demands set before the reading audience by modern literature did not resonate in most cases and that is one of the main reasons for a global shift in poetic paradigms that occurred in the 1980s. A referential reversal replaced a linguistic reversal; the signified in language replaced the hermeneutical and autistic language of modern literature. Truth be told, we cannot say 
that simple liberation from the "dungeon of language" helped bridge the gap between mass receptive competence and reader-interpretation standards that were inaugurated by writing practices and then academically canonized. We are more prone to the conviction that it is bridged by a magical bypass or simply ignored. In any case, not even literary "technocracy" closes its eyes before the (sometimes ethereal!) real reader, unaware of but also indifferent towards theories of possible worlds, superindividual sign structures and systems, literary conventions and norms, historical poetics and genre norms. Of the necessary "equipment", most readers possess tools from the non-aesthetic sphere - they are more or less prone to reconstruct sociohistorical milieus and, concretely, decorate them with the writer's "intentions" in the context of the supposed quest for an alibi for a personal act of conversion ${ }^{3}$. Such perception favors the view that Hasan's monologue is a pamphlet on the insufficiency of Bosniak ethnogenesis and it becomes a conjecture amongst the proponents of the thesis of "guilt resulting from apostasy" as a dominant form of denying national independence and identity. Those in favor of such ideas/ideologies can, to a greater or lesser extent, rely on the fact that real readers are mostly dedicated consumers of referential illusions and that in that sense they are not far from the prototypical readers - lovers from Dante's Second Circle of Hell - Paolo and Francesca, a brother-in-law and a sister-in-law, seduced by reading Lancelot's love affairs:

When as we read of the much-longer-for smile

Being by such a noble lover kissed,

This one, who ne'er from me shall be divided,

3 "I come from a Muslim family in Bosnia, my nationality is Serbian. I belong to Serbian literature, but the literary creativity in Bosnia and Herzegovina, to which I also belong, I take as native literary center, but not as a special literature of Serbo-Croatian language. I equally respect my origin and my commitment, because I am also connected to everything that has determined my personality and my work. Each attempt to separate that for any purpose, I would consider a misuse of my basic right guaranteed by the Constitution. Therefore, I belong to the nation and literature of Vuk, Matavulj, Stevan Sremac, Borislav Stanković, Petar Kočić, Ivo Andrić, and my deepest relationship with them I don't need to prove. Members of the editorial board of 'Serbian Literature in 100 Books', all of whom were members of the Serbian Academy of Arts and Sciences, were aware of that anyways, and they have been members of the Department of Languages and Literature with me: Mladen Leskovac, Dušan Matić, Vojislav Đurić, Boško Petrović. That why it is no accident that I'm writing this letter to the Serbian Academy of Arts and Sciences, with an explicit demand that it be deemed a trustworthy autobiographical note." (Selimović, 1976). 
Kissed me upon the mouth all palpitating.

Galeotto was the book and he who wrote it.

That day no farther did we read therein.

(Dante Aligieri: Inferno, Canto V, 133138)

A more profound form of referential reading usually reaches out for the narrative on the necessity of eliminating taboos and is open to re-reading a heritage from different points of view including the traditional concept of "ontological unity" of ethics and aesthetics. Those in favor of such an approach insist that if the aesthetic experience lacks a connection with the (empirical!) truth, the person becomes ignorant of the responsibility towards themselves and history, hence, Death and the Dervish is in such a view automatically stigmatized by ideological exploitation of aesthetics in favour of politics and victims are those who perceive fictional worlds as real.

Hasan commences the self-portrayal of the identity with a semantic ictus in medias res: "We are no one's... and soon we will not know who we are" (Selimović, 1975a, p. 340). The question is worth asking: who sees Bosniak identity as controversial - Bosniaks or those who deny their identity? Religion, culture, tradition, even a very broad array of ideological profiles formed in the $20^{\text {th }}$ century that includes atheists and agnostics is clearly differentiated in relation to the South-Slavic, Balkan, European, and Muslim peoples. The identity issue is a characteristic of those who have succumbed to assimilation tendencies and the pressure of declaring themselves as Serbs, Croats, Yugoslavs, or undeclared. In a hiatus of Hasan's dilemmas, a small fragment eroded, one which even rejection did not abolish, on the contrary, it only intensified the drama described in the monologue: “... we are losing our own persona and nor being able to take on anyone else's. Torn away and not accepted, alien to all and everyone, including those with whom we are most closely related, and to those who will not recognize us as their kin" (Selimović, 1975a, p. 341).

Historically, an ordinary man is crucified by existential rather than by identitary issues; he has unmistakably felt the limits and has managed to sustain himself the way he is (without losing) face in this "swamp" or rose garden - depending on the vantage point.

History did "play a joke with Bosniaks", but not because "only yesterday we were something that we now wish to forget" but because they did not learn from their historical experience (Selimović, 1975a, p. 419). If it is an allusion (and Selimović confirmed that in the aforementioned interview!) to the acceptance of Islam as a new faith and apostasy, then we are on a slippery slope of relativ- 
ism according to which the entire history of mankind would be the history of conversion, for the single purpose of reaching the ancient origin, something people call Qualy bela!

The defeatits tendency of the monologue climaxes in the ellipsis "There is no place we can go to anymore" (Selimović, 1975a, p. 419) which is, in the gradual sequence, a rhetorical consequence of comparison with the cripple Jamail and the image of a branch that streamed away from the mother river, so it is too small to be a lake, too big to be sapped by the earth. One should not underestimate the appeal and the effects of these stylistically seductive and impeccable generalizations, especially in a tendentious and extra-literary interpretation, which are frequent in communities contaminated by chauvinism. Moreover, within the theory of possible worlds, the effect of that kind is not entirely excluded, hence Darko Suvin points out: "Perception of the possible world in Leibniz's sense always offers a universe alternative to the existing, empirical, against which it stands in a two-way, dialogue relationship, since it is awoken by the empirical universe and it intervenes into it" (Suvin, 1988, p. 125).

In that sense, the need for a rigorous "dispute with Hasan" becomes even more obvious in the light of non-aesthetic perception, especially in the framework of school curricula, for, the open arena of the classroom setting has always been a place where public and moral values gain decisive importance. In spite of the incompatibility of the analytical standpoints, a focused combination of approaches appears as a pedagogical and methodological imperative, as a suspension instrument of the praxis in which an undisputable artistic value of a literary work serves as a shield to those who promote scientifically and historically suspicious and aesthetically plausible intertextual contexts as empirical truths.

\section{Instead of a Conclusion}

The realization that the world views of readers and writers do not have to necessarily match is assuaging, otherwise only the works whose view of life matches our own would be satisfactory. Although written a long time ago, René Wellek's thoughts sound very current:

We are willing to call a writer great when his world, although not matching our own in pattern and in scope, encompasses all readers whose presence we consider 
necessary for providing universal goals or when it includes that which is chosen as deep and main, and when the scale or hierarchy appears appealing for a grown man to adopt (Velek \& Voren, 1974, p. 257).

A precondition for that is work on oneself, acquiring competences and taking the best possible point of transgradience, which is a term Russian formalists use to mark all external elements (context, author, reader, tradition, ideology) that are important in relation towards the internal composition of the fictional world but functionally subordinated to the main constructive task - to create a coherent work (Medvedev, 1976). Coherent in accordance to the model of da Vinci's Last Supper: each participant - Christ and the apostles, take their unique position in the painting as a whole, and that whole cannot be understood by identification with the characters, rather, it presupposes a point of transgradience towards each of them and towards all of them.

Post-structural acquisitions of a semiological approach to the literary character can offer a creative juncture of the static and the dynamic, the cultural and the textual, as a chance for an efficient compromise integration a propos our thematic focus (Hamon, 2000, p. 438). The character in the text is signifie, and in order for it to function as a sign, a signifiant is ascribed to it - a name. Still, the literary markedness of a character, unlike linguistic markedness, is not a predetermined and stabile fact that simply needs to be recognized; rather, it is a complex construction, gradually revealed through reading - through an adventure that is "always a cooperation of the effects of the context, especially semantic and intertextual relations, memorizing and reconstruction performed by the reader" (Hamon, 2000, p. 439). I admit that the sense of a sign (character) determines the entire previous context, making one meaning amongst an array of meanings possible, and we have already broadened the notion of context to the text Histories and Cultures.

\section{BIBLIOGRAPHY}

Bahtin, M. (1991). Autor i junak u estetskoj komunikaciji. Novi Sad: Svetovi.

Beker, M. (1986). Suvremene književne teorije. Zagreb: SNL.

Biti, V. (2000). Pojmovnik suvrmene književne i kulturne torije. Zagreb: Matica hrvatska.

Eagleton, T. (1987). Književna teorija. Zagreb: Liber.

Eko, U. (2003). Šest šetnji po narativnoj šumi. Beograd: Narodna knjiga-Alfa. 
Foht, I. (1980). Uvod u estetiku. Sarajevo: Svjetlost.

Hamon, P. (2000). Za semiološki status lika. In C. Milanja (Ed.), Autor, pripovjedač, lik (zbornik radova) (pp. 429-477). Osijek: Svjetla grada - Sveučilište Josipa Jurja Štrosmajera.

Iser, W. (1986). Čitateljeva uloga u Fieldingovu Josephu Andrewsu. In M. Beker (Ed.), Suvremene književne teorije (pp. 273-287). Zagreb: SNL.

Jakobson, R. (1970). Viktor Hlebnjikov. In A. Petrov (Ed.), Poetika ruskogformalizma (pp. 95-117). Beograd: Prosveta.

Jergović, M. (2015). Samoća bosanskih Muslimana. Retrieved 10 April 2017, from http://www. jergovic.com/ajfelov-most/samoca-bosanskih-muslimana/

Kundera, M. (2015). Estetika i egzistencija. Retrieved 10 April 2017, from http://pulse.rs/ estetika-i-egzistencija

Lagumdžija, R. (1991). Mešina vječita uznemirenost. Sarajevo: Oslobođenje.

Langer, S. (1967). Filozofija u novome ključu. Beograd: Prosveta.

Leibniz, G. W. (1980). Izabrani filozofski spisi. Zagreb: Naprijed.

Medvedev, P. (1976). Formalni metod u nauci o književnosti. Beograd: Nolit.

Peleš, G. (1984). Književnost i obrazovanje. In A. Jovanović (Ed.), Kako predavati književnost (pp. 170-185). Beograd: Zavod za udžebnike.

Popović, R. (1988). Život Meše Selimovića. Beograd: BIGZ.

Selimović, M. (1975a). Derviš i smrt. Beograd - Rijeka: Sloboda - Otokar Keršovani.

Selimović, M. (1975b). Sabrana djela: Vol. 7. Pisci, mišljenja i razgovori. Beograd - Rijeka: Sloboda - Otokar Keršovani.

Selimović, M. (1976). Pismo Meše Selimovića Srpskoj Akademiji nauka i umetnosti iz novembra 1976. Retrieved 10 April 2017, from http://govori.tripod.com/mesa_selimovic.htm

Suvin, D. (1988). Izvedbeni tekst kao dijalog gledališta i scene koji pobuđuje mogući svijet. Republika, 44(7/8), 120-135.

Ustamujić, E. (1990). Oblici pripovijedanja u romanu Meše Selimovića. Mostar: Udruženje književnika BiH, Podružnica Mostar.

Velek, R., \& Voren, O. (1974). Teorija književnosti. Beograd: Nolit. 


\section{Jak czytać Hasana \\ albo zmartwychwstanie przypadkowego widma rzeczywistych czytelników}

Fragment powieści Derwisz i śmierć M. Selimovicia, słynny monolog Hasana na temat bośniackiej tożsamości, któremu poświęcono niniejszy artykuł, jest wyjątkowo podatny na manipulacje interpretacyjne. W tekście dokonano jego analizy, obierając dwa różne metodologiczne punkty wyjścia. Pierwszy typ lektury (podejście wewnętrzne) jest próbą rzucenia światła na estetyczną skuteczność soliloqium Hasana w kontekście struktury całości powieści. Drugi punkt wyjścia (podejście zewnętrzne) to odczytanie monologu jako auto-imagologicznego, politycznie zinstrumentalizowanego dyskursu. Celem tekstu jest także (implicit) próba odpowiedzi na pytanie, czy - mimo niezgodności punktów analitycznych - możliwe jest wiarygodne połączenie tych dwóch podejść, biorąc pod uwagę fakt, że zgodność poglądów pisarza i czytelnika nie jest koniecznym warunkiem wstępnym komunikacji estetycznej.

Słowa kluczowe: komunikacja estetyczna, lektura kontekstowa, teoria światów możliwych, upolitycznienie estetyki, czytelnik implikowany i rzeczywisty, imagologia, tożsamość, auto-definicje

\section{How To Read Hasan or The Resurrection of a Contingent Apparition of Real Readers}

A fragment from the novel Death and the Dervish, the famous monologue by Hasan about the Bosniak identity, to which this review is dedicated, is exceptionally appropriate for an interpretative manipulation. We have approached it from two different methodological starting points. The first reading (the inner approach) attempts to shed light on the aesthetic efficiency of Hasan's soliloquy in the context of the structure/totality of the novel. The second starting point (the outer approach) is reading the monologue as an auto-imagological, politically instrumentalized discourse. The text should also be understood as an implicit answer to the question of whether it is possible to plausibly combine these approaches despite the incompatibility of the analytical points, while considering the fact that the compatibility of the writer's and reader's worldview is not a necessary prerequisite for aesthetic communication.

Keywords: aesthetic communication, referential reading, the theory of possible worlds, the politicization of aesthetics, an implicit and actual reader, imagology, identity, auto-definitions 


\section{Notka o autorze}

Vedad Spahić (vedad.spahic@bih.net.ba) - literaturoznawca, profesor zwyczajny, wykładowca na Wydziale Humanistycznym i Nauk Społecznych Uniwersytetu w Tuzli. Zainteresowania naukowe: stara literatura bośniacko-hercegowińska, współczesna literatura bośniacko-hercegowińska, konstruowanie i reprezentacje tożsamości w literaturze bośniackiej.

Vedad Spahić, Prof. (vedad.spahic@bih.net.ba) - literary studies expert, full professor at the Faculty of Humanities and Social Sciences, University of Tuzla. Research interests: old Bosnian-Herzegovinian literature, contemporary Bosnian-Herzegovinian literature, construction and representation of identity in Bosnian literature. 